\title{
Response of Fodder Maize to Various Levels of Nitrogen and Phosphorus
}

\author{
Aziz Khan1*, Fazal Munsif', Kashif Akhtar², Muhammad Zahir Afridi², Zahoor3, \\ Zahoor Ahmad", Shah Fahad5, Rizwan Ullah', Faheem Ahmed Khan7, Mairaj Din ${ }^{8}$ \\ ${ }^{1}$ MOA Key Laboratory of Crop Eco-Physiology and Farming System in the Middle Reaches of the Yangtze River, \\ Hauzhong Agricultural University, Wuhan, China \\ ${ }^{2}$ Department of Agronomy, The University of Agriculture, Peshawar, Pakistan \\ ${ }^{3}$ National Key Laboratory of Crop Genetic Improvement, Huazhong Agricultural University, Wuhan, China \\ ${ }^{4}$ Key Lab of Vegetable and Plant Diseases Hubei Province, Wuhan, China \\ ${ }^{5}$ Crop Physiology and Production Center (CPPC), National Key Laboratory of Crop Genetic Improvement, MOA \\ Key Laboratory of Crop Eco-Physiology and Cultivation, Huazhong Agricultural University, Wuhan, China \\ ${ }^{6}$ Key Laboratory of Horticulture Plant Biology (MOE), Huazhong Agricultural University, Wuhan, China \\ ${ }^{7}$ Key Laboratory of Animal Genetics, Breeding, and Reproduction, Huazhong Agricultural University, Wuhan, \\ China \\ ${ }^{8}$ Moecular Biology Lab, College of Plant Science and Technology, Huazhong Agricultural University, Wuhan, \\ China \\ Email: ${ }^{*}$ aziz.hzau@gmail.com
}

Received 9 May 2014; revised 11 June 2014; accepted 25 June 2014

Copyright (C) 2014 by authors and Scientific Research Publishing Inc.

This work is licensed under the Creative Commons Attribution International License (CC BY). http://creativecommons.org/licenses/by/4.0/

(c) (i) Open Access

\section{Abstract}

Nitrogen (N) and Phosphorus (P) are of the most important and complex nutrients for the crop plants in particular for grain yield and quality. The field trials were laid out in randomized complete block design having three replications. Research trial plots were located at Agricultural Research Farm of Agricultural University Peshawar (Ameer Mohammad Khan Campus Mardan) during kharif season in 2012 to investigate the response of maize variety (Jalal) to three phosphorus rates $\left(60,90\right.$ and $\left.120 \mathrm{~kg} \cdot \mathrm{ha}^{-1}\right)$ and four nitrogen rates $\left(90,120,150,180 \mathrm{~kg} \cdot \mathrm{ha} \mathrm{a}^{-1}\right)$ for agronomical traits. These traits investigated included number of plant per $\mathrm{m}^{2}\left(\mathrm{NP}^{2}\right)$, plant height $(\mathrm{PH})$, number of leaves plant ${ }^{-1}$ (NLP), leaf area plant ${ }^{-1} \cdot \mathrm{cm}^{2}$ (LAP), fresh weight of plants $\mathrm{kg}^{-\mathrm{ha}^{-1}}$ (FW) and dry weight of plant $\mathrm{kg} \cdot \mathrm{ha} \mathrm{a}^{-1}$ (DW), were investigated. Results of the study showed that application of $\mathrm{N}$ @ 180 and $P @ 120 \mathrm{~kg} \cdot \mathrm{ha}^{-1}$ significantly increased fodder yield of maize. The linear increase in biomass yield clearly indicated that $\mathrm{N}$ was a limiting nutrient factor and that $\mathrm{N}$ demand along with $P$ has a positive response. At higher application rates, $\mathrm{N}$ fertilizer significantly increased biomass component, improved $\mathrm{N}$ uptake with increasing nitrogen use efficiency and decreased its losses to the environment and below plant zone. So this study showed that the phosphorus and nitrogen

\footnotetext{
${ }^{*}$ Corresponding author.
}

How to cite this paper: Khan, A., Munsif, F., Akhtar, K., Afridi, M.Z., Zahoor, Ahmad, Z., Fahad, S., Ullah, R., Khan, F.A. and Din, M. (2014) Response of Fodder Maize to Various Levels of Nitrogen and Phosphorus. American Journal of Plant Sciences, 5, 2323-2329. http://dx.doi.org/10.4236/ajps.2014.515246 
fertilizers have a positive effect on the fodder yield of maize.

\title{
Keywords
}

\author{
Fodder Maize, Nitrogen, Phosphorus
}

\section{Introduction}

Maize (Zea mays L.) is grown as dual purposes such as food, feed, and fodder crop in Pakistan. It plays important roles in both human diet animal feed and provides a large amount of energy and protein [1] [2]. It is most important constituent of cattle fodder and poultry feed [3]. In Pakistan, maize is the third important crop after wheat and rice. In the year 2010-2011, total area under maize crop in Pakistan was 974.3 thousand hectares with 3706.9 thousand tons of total production [4]. The main producers are India, Pakistan, Brazil, France, and Italy. Although the soil and climatic conditions of Pakistan are favorable for the maize production, but its per ha ${ }^{-1}$ fodder yield is very low as compared to other country of the world. Low yield of maize was due to many factors, but fertilizer application is considered one of the main factors which can increase fodder production on per unit area basis.

Nitrogen is a primary nutrient required by crop plants for their growth and development. Nitrogen plays a key role in vegetative growth and grain production of maize plant [5] [6]. The application of nitrogen not only affects the forage yield of maize, but also improves its quality especially its protein contents [7]. It is reported that application of nitrogen to maize increase fodder nutritive value by increasing crude protein and by reducing ash and fiber contents [8]. Plant height, stem diameter, green fodder yield, protein, fiber, and total ash content were increased by increasing nitrogen levels. Phosphorus is also considered an essential nutrient to plant growth and development. It is an integral part of nucleic acid and is essential for cellular respiration and for metabolic activity. Therefore, the use of phosphorus along with nitrogen will help increase yield of maize [9]. Previous studies suggested that phosphorus influenced both maize's forage yield and quality [10]. Phosphorus application increased fodder yield and quality by increasing plant height, and the number of leaves plant ${ }^{-1}$ [11]. The objective of this study was to determine the effectiveness of different phosphorus and nitrogen fertilizer on the fodder yield.

\section{Materials and Methods}

The field study was conducted at the Agricultural Research farm of Amir Mohammad khan Campus Mardan, the University of Agricultural Peshawar, Pakistan 2012. The experiment was laid out in randomized complete block design having three replications. The soil was ploughed with cultivator 2 to 3 times followed by planking. Four different levels of $\mathrm{N}\left(90,120,150\right.$ and $\left.180 \mathrm{~kg} \cdot \mathrm{ha}^{-1}\right)$ and three levels of $\mathrm{P}\left(60,90\right.$ and $\left.120 \mathrm{~kg} \cdot \mathrm{ha}^{-1}\right)$ were applied to each experimental unit. Maize variety “Jalal” was sown by broadcast method at the 1st week of July 2012. The net plot size was $4 \times 3 \mathrm{~m}^{2}$ used. Standard cultural practices for maize production were followed during growing season. Data recorded included on the number of plants $\mathrm{m}^{2}$, plant height $(\mathrm{cm})$, number of leaves plant ${ }^{-1}$, leaf area plant ${ }^{-1}\left(\mathrm{~cm}^{2}\right)$, fresh weight of plants $\mathrm{kg} \cdot \mathrm{ha}^{-1}$, dry weight of plants $\mathrm{kg} \cdot \mathrm{ha}^{-1}$.

\section{Statistical Analysis}

The replicated means were subjected to ANOVA using MS excel (2007). The least significant difference (LSD) was founded by using $\mathrm{p}<0.05$ that shows the results were significantly different.

\section{Results}

\subsection{Plant Density (Number of Plants $\mathrm{m}^{2}$ )}

Number of plant $\mathrm{m}^{2}$ is presented in Table 1 . Nitrogen levels had significantly increased the number of plant $\mathrm{m}^{2}$ while the effect of phosphorus on number of plants $\mathrm{m}^{2}$ not significant. Planed mean comparison showed that control vs rest (fertilized plots) was also found significant for the number of plant $\mathrm{m}^{2}$. Interaction between nitrogen and phosphorus levels was found not significant. Mean value of the data indicated that higher number of plants $\mathrm{m}^{2}$ (21) was observed when nitrogen was applied at the rate of $180 \mathrm{~kg} \mathrm{~N} \mathrm{ha}^{-1}$ followed by $150 \mathrm{~kg} \mathrm{~N}$ ha 
Table 1. Effect of different levels of nitrogen and phosphorus on number of plants $\mathrm{m}^{2}$.

\begin{tabular}{|c|c|c|c|c|c|}
\hline P kg.ha ${ }^{-1}$ & N1 $\mathrm{kg} \cdot \mathrm{ha}^{-1}$ & N2 $\mathrm{kg} \cdot \mathrm{ha}^{-1}$ & N3 $\mathbf{k g} \cdot \mathrm{ha}^{-1}$ & N4 $\mathrm{kg} \cdot \mathrm{ha}^{-1}$ & Means \\
\hline P1 & 14.0 & 17.7 & 20.7 & 21.0 & $20.8^{\mathrm{a}}$ \\
\hline P2 & 17.7 & 18.3 & 20.7 & 23.0 & $21.8^{\mathrm{a}}$ \\
\hline P3 & 20.7 & 22.0 & 18.3 & 21.0 & $19.7^{\mathrm{b}}$ \\
\hline Means & $17.4^{\mathrm{b}}$ & $19.3^{\mathrm{a}}$ & $19.9^{\mathrm{a}}$ & $21.7^{\mathrm{a}}$ & \\
\hline Control & \multirow{2}{*}{\multicolumn{4}{|c|}{ Control vs. rest }} & 12.7 \\
\hline Rest & & & & & 19.6 \\
\hline
\end{tabular}

$\mathrm{N} 1=90, \mathrm{~N} 2=120, \mathrm{~N} 3=150, \mathrm{~N} 4=180 \mathrm{~kg} \cdot \mathrm{ha}^{-1}$ and $\mathrm{P} 1=60, \mathrm{P} 2=90, \mathrm{P} 3=120 \mathrm{~kg} \cdot \mathrm{ha}^{-1}$. LSD value at $\mathrm{p} \leq 0.05$ for nitrogen $=2.48 . \mathrm{LSD}$ value at $\mathrm{p} \leq$ 0.05 for phosphorus $=2.15$.

(19) whereas plots where fertilized at rate of $90 \mathrm{~kg} \mathrm{~N} \mathrm{ha}^{-1}$ resulted in lower number of plants $\mathrm{m}^{2}$ (17). Control plots resulted in lowest number of pants $\mathrm{m}^{2}(12)$.

\subsection{Plant Height (cm)}

Data regarding to plant height is presented in Table 2. The plant height was influenced significantly by different levels of nitrogen. Significant increase in plant height was observed by higher nitrogen levels. While the effect of phosphorus was found not significant. Mean comparison showed that control vs rest was also significant for plant height of maize. Interaction between nitrogen and phosphorus levels was found not significant. Mean value of the data indicated that higher plant height $(120.6 \mathrm{~cm})$ was recorded when nitrogen was applied at the rate of $180 \mathrm{~kg} \mathrm{~N} \mathrm{ha}^{-1}$ followed by $150 \mathrm{~kg} \mathrm{~N} \mathrm{ha}^{-1}$ with plant height $(119.6 \mathrm{~cm})$ and $120 \mathrm{~kg} \mathrm{~N}^{-1}$ with plant height $(114.7 \mathrm{~cm})$. Nitrogen at $90 \mathrm{~kg} \cdot \mathrm{ha}^{-1}$ resulted lowest plant height $(78.3 \mathrm{~cm})$. Plant height was lower in control $(79.7 \mathrm{~cm})$ as compared to the rest $(108.3 \mathrm{~cm})$.

\subsection{Number of Leaves Plant ${ }^{-1}$}

Data containing number of leaves plant ${ }^{-1}$ are presented in Table 3. Nitrogen and phosphorus levels increased affected number of leaves plant ${ }^{-1}$. Mean comparison showed that control vs rest was found significant for number of leaves plant ${ }^{-1}$ of maize. In addition interaction between nitrogen and phosphorus levels was also found significant. Mean value of the data indicated that higher number of leaves plant ${ }^{-1}(12)$ was recorded when nitrogen was applied at the rate of $180 \mathrm{~kg} \cdot \mathrm{ha}^{-1}$ followed by $150 \mathrm{~kg} \mathrm{~N} \mathrm{ha}^{-1}$ with number of leaves plant ${ }^{-1}$ (11) and 120 $\mathrm{kg} \mathrm{N} \mathrm{ha}^{-1}$ with number of leaves plant ${ }^{-1}(10)$. Nitrogen at $90 \mathrm{~kg} \cdot \mathrm{ha}^{-1}$ resulted lower number of leaves plant ${ }^{-1}(8)$. While in case of phosphorus the higher number of leaves plant $^{-1}$ (11) was recorded when phosphorus was applied at the rate of $120 \mathrm{~kg} \mathrm{P} \mathrm{ha}^{-1}$ followed by $90 \mathrm{~kg} \mathrm{P} \mathrm{ha}^{-1}$ with number of leaves plant ${ }^{-1}(10)$. Where $60 \mathrm{~kg} \mathrm{P}$ $\mathrm{ha}^{-1}$ resulted lower number of leaves plant ${ }^{-1}(9)$. Interaction between nitrogen and phosphorus showed that application of $\mathrm{P}$ at rate of $120 \mathrm{~kg} \mathrm{P} \mathrm{ha}^{-1}$ increased no of leaves along with $\mathrm{N}$ at $180 \mathrm{~kg} \mathrm{~N}^{-1}$. Control vs rest indicated that number of leaves plant $^{-1}$ (10.6) was higher in rest of the plots as compared to control (9).

\subsection{Leaf Area Plant ${ }^{-1}\left(\mathrm{~cm}^{2}\right)$}

Data concerning leaf area is presented in Table 4. The leaf area was positively influenced by different levels of nitrogen but, the effect of phosphorus was found non-significant for the leaf area of maize. Interaction between nitrogen and phosphorus levels was also not significant. Mean comparison showed that control vs. rest was found significant for leaf area of maize plant. Mean value of the data indicated that higher leaf area $\left(348 \mathrm{~cm}^{2}\right)$ was recorded when nitrogen was applied at the rate of $180 \mathrm{~kg} \cdot \mathrm{ha}^{-1}$ followed by $150 \mathrm{~kg} \cdot \mathrm{ha}^{-1}$ with leaf area (309 $\left.\mathrm{cm}^{2}\right)$ and $120 \mathrm{~kg} \cdot \mathrm{ha}^{-1}$ with leaf area $\left(290 \mathrm{~cm}^{2}\right)$. Where the $90 \mathrm{~kg} \cdot \mathrm{ha}^{-1}$ resulted in lower leaf area $\left(242 \mathrm{~cm}^{2}\right)$. Control vs rest indicated that leaf area of plants was higher $\left(297 \mathrm{~cm}^{2}\right)$ in rest of the treatment as compared to control $\left(202 \mathrm{~cm}^{2}\right)$.

\subsection{Fresh Fodder Yield (kg•ha-1)}

Data pertaining fresh weight of plants $\left(\mathrm{kg} \cdot \mathrm{ha}^{-1}\right)$ is presented in Table 5. Nitrogen and phosphorus levels were 
Table 2. Effect of different levels of nitrogen and phosphorus on plant height $(\mathrm{cm})$.

\begin{tabular}{|c|c|c|c|c|c|}
\hline$P$ kg $\cdot h a^{-1}$ & N1 $\mathbf{k g} \cdot \mathrm{ha}^{-1}$ & N2 $\mathbf{k g} \cdot \mathrm{ha}^{-1}$ & N3 $\mathrm{kg} \cdot \mathrm{ha}^{-1}$ & $\mathrm{~N} 4 \mathrm{~kg} \cdot \mathrm{ha}^{-1}$ & Means \\
\hline P1 & 69.0 & 113.3 & 109.3 & 120.3 & $91.2^{\mathrm{a}}$ \\
\hline P2 & 81.3 & 126.3 & 111.7 & 125.3 & $103.8^{\mathrm{b}}$ \\
\hline P3 & 84.7 & 104.3 & 137.7 & 116.7 & $94.5^{\mathrm{a}}$ \\
\hline Means & $78.3^{\mathrm{b}}$ & $114.7^{\mathrm{a}}$ & $119.6^{\mathrm{a}}$ & $120.8^{\mathrm{a}}$ & \\
\hline Control & \multirow{2}{*}{\multicolumn{4}{|c|}{ Control vs. rest }} & 79.7 \\
\hline Rest & & & & & 108.3 \\
\hline
\end{tabular}

$\mathrm{N} 1=90, \mathrm{~N} 2=120, \mathrm{~N} 3=150, \mathrm{~N} 4=180 \mathrm{~kg} \cdot \mathrm{ha}^{-1}$ and $\mathrm{P} 1=60, \mathrm{P} 2=90, \mathrm{P} 3=120 \mathrm{~kg} \cdot \mathrm{ha}^{-1}$. LSD value at $\mathrm{p} \leq 0.05$ for nitrogen $=16.03$. LSD value at $\mathrm{p} \leq$ 0.05 for phosphorus $=13.88$.

Table 3. Effect of different levels of nitrogen and phosphorus on number of leaves plant ${ }^{-1}$.

\begin{tabular}{|c|c|c|c|c|c|}
\hline P kg.ha ${ }^{-1}$ & N1 $\mathbf{k g} \cdot \mathrm{ha}^{-1}$ & N2 $\mathbf{k g} \cdot \mathrm{ha}^{-1}$ & N3 $\mathrm{kg} \cdot \mathrm{ha}^{-1}$ & N4 kg.ha ${ }^{-1}$ & Means \\
\hline P1 & 8.0 & 11.0 & 9.7 & 10.7 & $9.8^{\mathrm{a}}$ \\
\hline $\mathbf{P 2}$ & 9.0 & 10.7 & 10.0 & 13.3 & $10.8^{\mathrm{b}}$ \\
\hline P3 & 12.0 & 9.3 & 10.7 & 12.7 & $11.2^{\mathrm{a}}$ \\
\hline Means & $8.5^{c}$ & $10.8^{\mathrm{ab}}$ & $9.8^{\mathrm{b}}$ & $12.0^{\mathrm{a}}$ & \\
\hline $\begin{array}{c}\text { Control } \\
\text { Rest }\end{array}$ & \multicolumn{4}{|c|}{ Control vs. rest } & $\begin{array}{c}9.0 \\
10.6\end{array}$ \\
\hline
\end{tabular}

$\mathrm{N} 1=90, \mathrm{~N} 2=120, \mathrm{~N} 3=150, \mathrm{~N} 4=180 \mathrm{~kg} \cdot \mathrm{ha}^{-1}$ and $\mathrm{P} 1=60, \mathrm{P} 2=90, \mathrm{P} 3=120 \mathrm{~kg} \cdot \mathrm{ha}^{-1} . \mathrm{D}$ value at $\mathrm{p} \leq 0.05$ for nitrogen $=1.28 . \mathrm{D}$ value at $\mathrm{p} \leq 0.05$ for phosphorus $=1.11$.

Table 4. Effect of different levels of nitrogen and phosphorus on leaf area plant $^{-1}\left(\mathrm{~cm}^{2}\right)$.

\begin{tabular}{|c|c|c|c|c|c|}
\hline P kg $\cdot \mathrm{ha}^{-1}$ & N1 $k g \cdot h a^{-1}$ & $\mathrm{~N} 2 \mathrm{~kg} \cdot \mathrm{ha}^{-1}$ & N3 $\mathbf{k g} \cdot \mathrm{ha}^{-1}$ & $\mathrm{~N} 4 \mathrm{~kg} \cdot \mathrm{ha}^{-1}$ & Means \\
\hline P1 & 241.7 & 305.7 & 298.3 & 316.7 & $281.9^{\mathrm{a}}$ \\
\hline $\mathbf{P} 2$ & 269.0 & 170.0 & 318.3 & 371.7 & $252.4^{\mathrm{a}}$ \\
\hline P3 & 360.0 & 251.3 & 310.0 & 358.0 & $307.1^{\mathrm{b}}$ \\
\hline Means & $290.2^{c}$ & $242.3^{\text {bc }}$ & $308.9^{\mathrm{b}}$ & $348.8^{\mathrm{a}}$ & \\
\hline $\begin{array}{c}\text { Control } \\
\text { Rest }\end{array}$ & \multicolumn{4}{|c|}{ Control vs. rest } & $\begin{array}{l}202.0 \\
297.6\end{array}$ \\
\hline
\end{tabular}

$\mathrm{N} 1=90, \mathrm{~N} 2=120, \mathrm{~N} 3=150, \mathrm{~N} 4=180 \mathrm{~kg} \cdot \mathrm{ha}^{-1}$ and $\mathrm{P} 1=60, \mathrm{P} 2=90, \mathrm{P} 3=120 \mathrm{~kg} \cdot \mathrm{ha}^{-1}$. D value at $\mathrm{p} \leq 0.05$ for nitrogen $=56.46 . \mathrm{D}$ value at $\mathrm{p} \leq 0.05$ for phosphorus $=48.88$.

Table 5. Effect of different levels of nitrogen and phosphorus on fresh fodder yield of maize.

\begin{tabular}{|c|c|c|c|c|c|}
\hline P kg.ha ${ }^{-1}$ & N1 $\mathbf{~ k g} \cdot \mathrm{ha}^{-1}$ & N2 $\mathbf{~ k g} \cdot \mathrm{ha}^{-1}$ & N3 kg $\cdot h a^{-1}$ & N4 $\mathbf{k g} \cdot \mathrm{ha}^{-1}$ & Means \\
\hline P1 & 13000 & 19666 & 21666 & 19000 & $18111 b$ \\
\hline P2 & 19000 & 22333 & 17333 & 24666 & $1955^{\mathrm{ab}}$ \\
\hline P3 & 20000 & 17666 & 24000 & 25666 & $2055^{\mathrm{a}}$ \\
\hline Means & $17333^{c}$ & $19889^{\mathrm{bc}}$ & $21000^{\mathrm{ab}}$ & $23111^{\mathrm{a}}$ & \\
\hline $\begin{array}{c}\text { Control } \\
\text { Rest }\end{array}$ & \multicolumn{4}{|c|}{ Control vs. rest } & $\begin{array}{l}11333 \\
20333\end{array}$ \\
\hline
\end{tabular}

$\mathrm{N} 1=90, \mathrm{~N} 2=120, \mathrm{~N} 3=150, \mathrm{~N} 4=180 \mathrm{~kg} \cdot \mathrm{ha}^{-1}$ and $\mathrm{P} 1=60, \mathrm{P} 2=90, \mathrm{P} 3=120 \mathrm{~kg} \cdot \mathrm{ha}^{-1} . \mathrm{D}$ value at $\mathrm{p} \leq 0.05$ for nitrogen $=1.03 . \mathrm{D}$ value at $\mathrm{p} \leq 0.05$ for phosphorus $=0.89$. 
found significant on fresh weight of plants. Interaction between nitrogen and phosphorus levels was also found significant. Mean comparison showed that control vs rest was significant for fresh weight of maize plants. Mean value of the data indicated that higher fresh weight $\left(2375.9 \mathrm{~kg} \cdot \mathrm{ha}^{-1}\right)$ was recorded when nitrogen was applied at the rate of $180 \mathrm{~kg} \mathrm{~N} \mathrm{ha}^{-1}$ followed by $150 \mathrm{~kg} \mathrm{~N} \mathrm{ha}{ }^{-1}$ with fresh weight $\left(1771.3 \mathrm{~kg} \cdot \mathrm{ha}^{-1}\right)$ and $120 \mathrm{~kg} \mathrm{~N} \mathrm{ha}{ }^{-1}$ with fresh weight $\left(1490.7 \mathrm{~kg} \cdot \mathrm{ha}^{-1}\right.$ where $90 \mathrm{~kg} \mathrm{~N} \mathrm{ha}^{-1}$ resulted in lowest fresh weight $\left(1101.9 \mathrm{~kg} \cdot \mathrm{ha}^{-1}\right)$. While in case of phosphorus the higher fresh weight $\left(1764.6 \mathrm{~kg} \cdot \mathrm{ha}^{-1}\right)$ was recorded when phosphorus was applied at the rate of $120 \mathrm{~kg} \mathrm{P} \mathrm{ha}^{-1}$ followed by $90 \mathrm{~kg} \mathrm{P} \mathrm{ha}{ }^{-1}$ with fresh weight $\left(1668.8 \mathrm{~kg} \cdot \mathrm{ha}^{-1}\right)$. Phosphorus at $60 \mathrm{~kg} \cdot \mathrm{ha}^{-1}$ resulted lowest fresh weight $\left(1621.5 \mathrm{~kg} \cdot \mathrm{ha}^{-1}\right)$. Interaction between $\mathrm{N}$ and $\mathrm{P}$ showed that application of $\mathrm{P}$ at the rate of 120 $\mathrm{kg} \mathrm{P} \mathrm{ha}{ }^{-1}$ increased fresh weight $\left(2447 \mathrm{~kg} \cdot \mathrm{ha}^{-1}\right)$ along with $\mathrm{N}$ at $180 \mathrm{~kg} \mathrm{~N} \mathrm{ha}^{-1}$. Control vs rest indicates that fresh weight $\left(888.9 \mathrm{~kg} \cdot \mathrm{ha}^{-1}\right)$ was lower in control compare to the rest $\left(1685 \mathrm{~kg} \cdot \mathrm{ha}^{-1}\right)$.

\subsection{Dry Fodder Yield (kg·ha-1)}

Data regarding dry weight of plants $\left(\mathrm{kg} \cdot \mathrm{ha}^{-1}\right)$ is presented in Table 6. Nitrogen and phosphorus levels were significant on dry weight of plants. Interaction between nitrogen and phosphorus levels were also significant. Mean comparison showed that control vs rest was significant for dry weight of maize plants. Mean value of the data indicated that higher dry weight $\left(952.8 \mathrm{~kg} \cdot \mathrm{ha}^{-1}\right)$ was recorded when nitrogen was applied at the rate of $180 \mathrm{~kg} \mathrm{~N}$ $\mathrm{ha}^{-1}$ followed by $150 \mathrm{~kg} \mathrm{~N} \mathrm{ha}^{-1}$ with dry weight $\left(727.8 \mathrm{~kg} \cdot \mathrm{ha}^{-1}\right)$ and $120 \mathrm{~kg} \mathrm{~N} \mathrm{ha}^{-1}$ with dry weight $(684.3$ $\left.\mathrm{kg} \cdot \mathrm{ha}^{-1}\right)$. While lower nitrogen rate $\left(90 \mathrm{~kg} \cdot \mathrm{ha}^{-1}\right)$ resulted lowest dry weight $\left(538.9 \mathrm{~kg} \cdot \mathrm{ha}^{-1}\right)$. For phosphorus the highest dry weight (827.1 kg.ha ${ }^{-1}$ ) was recorded when phosphorus was applied at the rate of $120 \mathrm{~kg} \mathrm{P} \mathrm{ha}{ }^{-1}$ followed by $90 \mathrm{~kg} \mathrm{P} \mathrm{ha}{ }^{-1}$ with dry weight $\left(720.1 \mathrm{~kg} \cdot \mathrm{ha}^{-1}\right)$. Phosphorus $60 \mathrm{~kg} \cdot \mathrm{ha}^{-1}$ resulted lowest dry weight (630.6 $\mathrm{kg} \cdot \mathrm{ha}^{-1}$ ). Interaction between $\mathrm{N}$ and $\mathrm{P}$ showed that application of $\mathrm{P}$ at rate of $120 \mathrm{~kg} \mathrm{P} \mathrm{ha}^{-1}$ increased dry weight $\left(1444.4 \mathrm{~kg} \cdot \mathrm{ha}^{-1}\right)$ along with $\mathrm{N}$ at $180 \mathrm{~kg} \mathrm{~N} \mathrm{ha}{ }^{-1}$. Control plots resulted lowest dry weight $\left(519.4 \mathrm{~kg} \cdot \mathrm{ha}^{-1}\right)$ as compared to rest of the plots $\left(725.9 \mathrm{~kg} \cdot \mathrm{ha}^{-1}\right)$.

\section{Discussion}

The effect of nitrogen levels was found significant for number of plant $\mathrm{m}^{2}$ while the effect of phosphorus on number of plants $\mathrm{m}^{2}$ was found non-significant. Interaction between nitrogen and phosphorus levels was found not significant. Plant density exerts a strong influence on maize growth, because of its competitive effect both on the vegetative and reproductive development [12] [13].

The effect of nitrogen levels was found significant on plant height while phosphorus was found not significant. Interaction between nitrogen and phosphorus levels was also found not significant. It is reported that high plant population results in enhancing plant height [14]. Plant competition to light is the main reason for higher plants at dense populations [15]. It is reported that plant density and planting pattern did not affect corn height [16]. Higher plant densities reduced leaves number per plant by enhancing interplant competition [17].

Effect of nitrogen and phosphorus levels was found significant on number of leaves plant ${ }^{-1}$. Also, it's concluded that nitrogen increase leaf length, number of leaves plant $^{-1}$ [18] [19].

Nitrogen levels had significantly affected leaf area of maize plant and the effect of phosphorus was found not significant. The probable reason of our result might be that $\mathrm{N}$ increase vegetative growth while $\mathrm{P}$ brings maturity in plant. These are in confirmation with those of [20] [21] who reported that leaf area increased with increase nitrogen and phosphorus levels.

Table 6. Effect of different levels of nitrogen and phosphorus on dry fodder yield of maize.

\begin{tabular}{|c|c|c|c|c|c|}
\hline P kg.ha ${ }^{-1}$ & N1 $k g \cdot h a^{-1}$ & N2 $\mathbf{k g} \cdot \mathrm{ha}^{-1}$ & N3 $\mathrm{kg} \cdot \mathrm{ha}^{-1}$ & N4 $\mathrm{kg} \cdot \mathrm{ha}^{-1}$ & Means \\
\hline P1 & 7000 & 9233 & 9266 & 10166 & $8916^{\mathrm{b}}$ \\
\hline P2 & 9366 & 10033 & 10200 & 9500 & $9775^{\mathrm{ab}}$ \\
\hline P3 & 9966 & 8933 & 10066 & 12166 & $10283^{\mathrm{a}}$ \\
\hline Means & $8777^{\mathrm{b}}$ & $9400^{\mathrm{b}}$ & $9844^{\mathrm{ab}}$ & $10611^{\mathrm{a}}$ & \\
\hline Control & \multirow{2}{*}{\multicolumn{4}{|c|}{ Control vs. rest }} & 5666 \\
\hline Rest & & & & & 9658 \\
\hline
\end{tabular}

$\mathrm{N} 1=90, \mathrm{~N} 2=120, \mathrm{~N} 3=150, \mathrm{~N} 4=180 \mathrm{~kg} \cdot \mathrm{ha}^{-1}$ and $\mathrm{P} 1=60, \mathrm{P} 2=90, \mathrm{P} 3=120 \mathrm{~kg} \cdot \mathrm{ha}^{-1} . \mathrm{D}$ value at $\mathrm{p} \leq 0.05$ for nitrogen $=0.15 . \mathrm{D}$ value at $\mathrm{p} \leq 0.05$ for phosphorus $=0.13$. 
The effects of nitrogen and phosphorus levels were found significant on fresh weight of plants. Interaction between nitrogen and phosphorus levels was also found significant. The probable reason might be that $\mathrm{N}$, and $\mathrm{P}$ enhanced the vegetative growth of maize plant. Our result is same with previous studies who reported fresh fodder yield increased with increase in nitrogen level [11] [21] [22].

The effect of nitrogen and phosphorus levels was found significant on dry weight of plants. Interaction between nitrogen and phosphorus levels was also found significant. The probable reason of our result might be that $\mathrm{N}$ and $\mathrm{P}$ increase number of leaves, plant height, leaf area, and vegetative growth due to which dry weight also increased. Our results are in confirmation with those of the previous studies [1] [11] [22] who reported that dry fodder yield increased with increase in phosphorus and nitrogen levels.

\section{Conclusion}

The fertilizer treatments significantly affected the yield and quality parameters tested in the present study. The increase in fodder yield with fertilizer application may be due to the greater plant height, the higher stem diameter, the higher number of leaves plant ${ }^{-1}$ and the higher leaf area plant ${ }^{-1}$. Thus, it can be concluded that the maize grown for fodder purpose and the optimum and economical dose of fertilizer for fodder crop of maize cultivar in agroecological condition of Mardan is $180-120 \mathrm{~kg} \mathrm{~N}^{-\mathrm{P} \mathrm{ha}}{ }^{-1}$.

\section{References}

[1] Anonymous (2000) Fertilizers and Their Use. FAO, International Industry Association, Rome, 35-38.

[2] Maiti, R.K. and Wesche-Ebeling, P. (1998) Maize Science. Oxford and IBH Publishing CO. Pvt. Ltd., New Dehli, Culcutta, 323.

[3] Chaudhary, R.V. and Khade, S.T. (1991) Growth and Yield Analysis of Sorghum Hybrid as Affected by NPK. Annals of P Physiology, 5, 97-102.

[4] Fahad, S. and Bano, A. (2012) Effect of Salicylic Acid on Physiological and Biochemical Characterization of Maize Grown in Saline Area. Pakistan Journal of Botany, 44, 1433-1438.

[5] Adediran, J.A. and Banjoko, V.A. (1995) Response of Maize to Nitrogen, Phosphorus and Potassium Fertilizers in the Savanna Zone of Nigeria. Communications in Soil Science and Plant Analysis, 26, 593-606. http://dx.doi.org/10.1080/00103629509369320

[6] Shanti, K.V.P., Rao, M.R., Reddy, M.S. and Sarma, R.S. (1997) Response of Maize (Zea mays) Hybrid and Composite to Different Levels of Nitrogen. Indian Journal of Agricultural Sciences, 67, 424-425.

[7] Haque, M.M., Hamid, A. and Bhuiyan, N.I. (2001) Nutrient Uptake and Productivity as Affected by Nitrogen and Potassium Application Levels in Maize/Sweet Potato Intercropping System. Korean Journal of Crop Science, 46, 1-5.

[8] Baran, M. (1987) Effect of Nitrogen Application on the Production and Nutritive Value of Maize and Soya Bean Mixture. Polnohespodarstov, 37, 613-624.

[9] Safdar, Z. (1997) Optimization of Nitrogen and Its Effect on Yield and Quality of Maize Fodder. M.Sc. (Hons.) Agriculture Thesis, University of Agriculture, Faisalabad, Pakistan.

[10] Patel, J.R., Thaker, K.R., Patel, A.C. and Parmer, H.P. (1997) Effects of Seed Rate and Nitrogen and Phosphorus Levels on Forage Maize Varieties. Gurat Agric. Uni. Res. J., 23, 1-8.

[11] Masood, T., Gul, R., Munsif, F., Jalal, F., Hussain, Z., Noreen, N., Khan, H., Din, N. and Khan, H. (2011) Effect of Different Phosphorus Levels on the Yield and Yield Components of Maize. Sarhad Journal of Agriculture, 27, 167170.

[12] Onasanya, R.O., Aiyelari, O.P., Onasanya, A., Oikeh, S., Nwilene, F.E. and Oyelakin, O. (2009) Growth and Yield Response of Maize (Zea mays L.) to Different Rates of Nitrogen and Phosphorus Fertilizers in Southern Nigeria. WJAS, 5, 400-407.

[13] Singh, D. and Choudhary, J. (2008) Effect of Plant Population and Fertilizer Levels on Yield and Economics of Pop Corn. Indian Journal of Plant Sciences, 78, 370-371.

[14] Demots-Mainard, S. and Pellerin, S. (1992) Effect of Mutual Shading on the Emergence of Nodal Roots and the Root/ Shoot Ratio of Maize. Plant and Soil, 147, 87-93. http://dx.doi.org/10.1007/BF00009374

[15] Muchow, R.C., Sinclair, T.R. and Bennett, J.M. (1990) Temperature and Solar Radiation Effects on Potential Maize Yield across Locations. Agronomy Journal, 82, 338-343. http://dx.doi.org/10.2134/agronj1990.00021962008200020033x

[16] Siadat, S.A. and Hasemi-Dezfouli, S.A. (2000) Effect of Plant Density and Planting Pattern of Grain Yield and Yield 
Components of Corn (Zea mays L.) Hybrid KSC 704. Agricultural Science Journal, 9, 39-48.

[17] Konuskan, O. (2000) Effect of Plant Density on Yield and Yield Related Characters of Some Maize Hybrids Grown at Hatay Conditions as 2nd Crop. M.Sc. Thesis, Science Institute, M.K.U., 71.

[18] Ali, J., Bakht, J., Shafi, M., Khan, S. and Shah, W.A. (2002) Uptake of Nitrogen as Affected by Various Combinations of Nitrogen and Phosphorus. Asian Journal of Plant Sciences, 1, 367-369. http://dx.doi.org/10.3923/ajps.2002.367.369

[19] Zahoor (2014) Influence of Integrated Use of Chemical and Organic Fertilizers on Yield and Yield Components of Wheat. International Journal of Agriculture and Crop Sciences, 7, 21-25.

[20] Khan, M.A., Khan, M.U., Ahmad, K. and Sadiq, M. (1999) Yield of Maize Hybrid-3335 as Affected by NP Levels. Pakistan Journal of Biological Sciences, 2, 857-859. http://dx.doi.org/10.3923/pjbs.1999.857.859

[21] Ayub, M., Nadeem, M.A., Sharar, M.S. and Mahmood, N. (2002) Response of Maize (Zea mays L.) Fodder to Different Levels of Nitrogen and Phosphorus. Asian Journal of Plant Sciences, 1, 352-354. http://dx.doi.org/10.3923/ajps.2002.352.354

[22] Dobos, A. and Nagy, J. (1998) Effects of Year and Fertilizer Application on Dry Matter Production of Maize. Novenytermeles, 47, 513-524. 
Scientific Research Publishing (SCIRP) is one of the largest Open Access journal publishers. It is currently publishing more than 200 open access, online, peer-reviewed journals covering a wide range of academic disciplines. SCIRP serves the worldwide academic communities and contributes to the progress and application of science with its publication.

Other selected journals from SCIRP are listed as below. Submit your manuscript to us via either submit@scirp.org or Online Submission Portal.
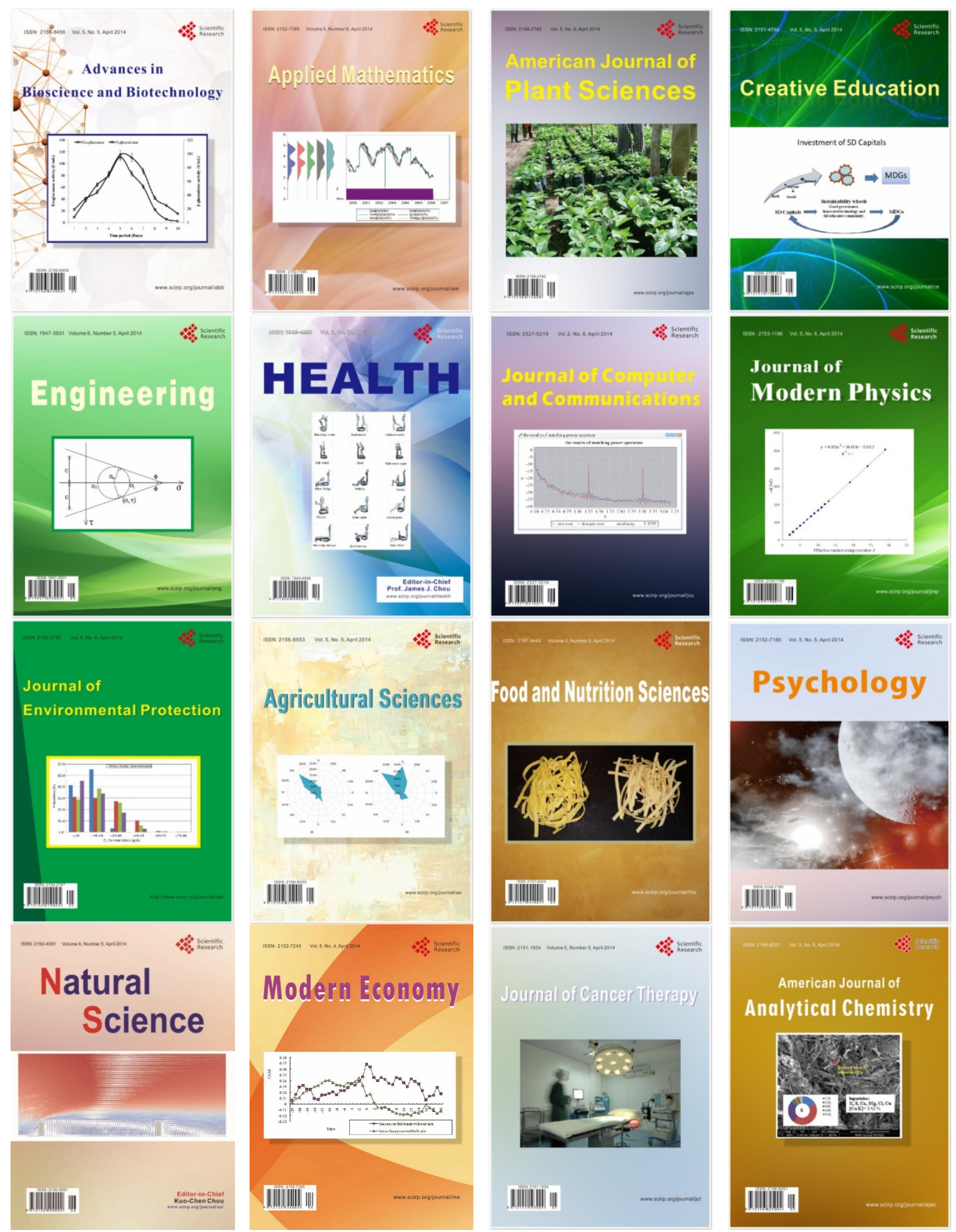